\title{
函館港内の流動と水質の変動特性について VARIATION CHARACTERISTICS OF TIDAL CURRENT AND WATER QUALITY IN HAKODATE PORT
}

\author{
宮武 誠 ${ }^{1}$ - 吉江祐人 ${ }^{2}$ - 湊 賢一 ${ }^{3}$ - 松村一弘 ${ }^{4}$ \\ Makoto MIYATAKE, Yuto YOSHIE,Ken-ichi MINATO and Kazuhiro MATSUMURA \\ ${ }^{1}$ 正会員 博 (工) 函館工業高等専門学校 環境都市工学科 ( T 042-8501 函館市戸倉町 14 番 1 号) \\ 2 学生員 函館工業高等専門学校 専攻科環境システム工学専攻 ( ₹ 042-8501 函館市戸倉町 14 番 1 号) \\ ${ }^{3}$ 博 (工）函館工業高等専門学校 電気電子工学科（００42-8501 函館市戸倉町 14 番 1 号） \\ ${ }^{4}$ 博（水）北海道立工業技術センター 機械電子技術科（ ₹ 041-0801 函館市桔梗町 379 番）
}

\begin{abstract}
The variation characteristics of tidal current and water quality in Hakodate port are investigated through field observation and numerical modeling. Measurements of nutrients, dissolved oxygen, chemical oxygen demand and turbidity are obtained from the whole area of the port. The results show that, during falling tide, the sediments suspension lead to increasing of chemical oxygen demand concentration. This phenomenon is made oxygen consumption speed to accelerate near the seabed. The phosphorus accumulated into the port is supplied from one of the rivers flowing out to Hakodate bay. The daily variation of water quality in the port is estimated using the multi-level model concerned with the ecological system. The results of prediction are in good qualitative agreement with those of observation.
\end{abstract}

Key Words: Hakodate port, field observation, sediment suspension, nutrients supply, multi-level model

\section{1.はじめに}

函館市では現在，「国際水産・海洋未来都市構想」 に際し，函館ドック跡地に国産水産・海洋総合研究セ ンターを建設することや，マリーンレジャーの場及び 大型蓄養施設として函館港の港奥海域を利用寸る構想 が計画されている ${ }^{1)}$. しかし, これまでの港湾は, 静 穏度の確保や荷役作業の安全性に重点が置かれ整備さ れているため, 特に港奥海域では閉鎖性が強く, 水質 の悪化が問題となることがある。函館港の港奥海域に おいても, 長年に渡る造船業や水産業により水質の悪 化が懸念されるが，過去に函館港を対象とした港内の 流動や水質の変動特性を詳細に取り扱った研究は見当 たらない.

本研究は，函館港港奥海域の水質と水位に関する 1 昼夜連続観測及び淮 3 次元多層モデルによる流動計算 から港内の流動外力を特定するとともに, 港奥海域の 水質変動メカニズムを解明する。更に港湾全域を対象 とした水質の長期観測及びトレーサ粒子による追跡解 析により港奥海域に蓄積する栄養塩の供給源について 検討する．また，これらの結果に基づき，今後実施予 定の自律駆動型水素吸蔵合金アクチュエータによる海
水交換装置 ${ }^{2)}$ の現地実験に際して, 装置運用後の港内 の水質改善効果や，港湾周辺海域の水質環境に及ぼす 影響を定量的に予測・評価可能な函館港における準 3 次元水質環境モデルを構築し，その予測精度やモデル の妥当性を検証するものである.

\section{2. 函館港港奥海域の流動と水質の日変動特性}

\section{（1）函館港西埠頭前面海域における 1 昼夜連続観測}

港内港奥海域の水質と水位に関する日変動特性を把 握するため, 西埠頭 $-6.5 \mathrm{~m}$ 岸壁前面海域において 1 昼 夜連続観測を実施した。図-1は，現地観測の調查位 置を示す. 1 昼夜連続観測は図中の St -0 地点におい て, 2008 年 9 月 27 日〜 28 日に実施した。.また, 図 中に示寸 $\mathrm{St}-1 \sim \mathrm{St}-4$ は後述する港湾全域を対象した 水質観測で使用する. 1 昼夜観測の計測項目を表 -1 に示寸. 水位は自記式圧力計により, 毎正時 20 分間, 0.5 秒のサンプリング間隔で計測した. D 0 ( 溶存酸素 量) 及び水温, $\mathrm{Cl}$ ( 塩素量) は, 水深方向に 3 層設け, それぞれ T.P. から $-2 \mathrm{~m}$ (上層)， $-4 \mathrm{~m}$ (中層)， $-6 \mathrm{~m}$ (下 層) 地点の值を 1 時間間隔で正時毎に計測した。濁度, 
T-P ( 全リン量), COD (化学的酸素要求量) は深さ方 向に D 0 と同様の上層, 中層, 下層地点の海水を採水 器により採取した後, 吸光光度計 (HACH 社製 DR/890 USEPA 法準拠）によって 6 時間間隔で計測した。

\section{（2）港奥海域における流動外力の検討}

図 -2（a）及び（b）は，観測期間中の風速ベクトルな らびに, 定時毎に得た 20 分間の水圧データから算出 した有義波高及び長周期波高の経時変化を示す。図中 に示寸長周期波高は周期が 30 秒から 600 秒に相当す る波を対象として表示する。観測期間中, 最も有義波 高が高くなる 9/27の 12:00 から 20:00には, 風速 5m/ $\mathrm{s}$ 以上の風が時間経過とともに西北西から西方向へ向 きを転じながら卓越する。しかし，20:00 以降には風 向を北東に転じ, 風速が減速した結果, 有義波高もそ れに伴い減少する. 有義波高は, その 8 割程度が長周 期波高であることから，港奥海域の波浪は長周期波成 分が卓越し，その消長は観測期間中に生じた風に支配 的であると考えられる.

図 -3 (a) は毎定時 20 分間に得られた 0.5 秒間隔の 水圧データを用いて, FFT によるスペクトル解析を行っ た結果を示寸. 周期 10 秒以下で一部パワースペクト ルにピークがみられるものの，そのほとんどは周期 が 30 秒から 600 秒の間に集中寸る. 寸べてのケース において, 周期 500 秒付近で明確なパワースペクトル にピークが認められる。これは港内を矩形とし，観測 当時発生頻度の高かった風向方向に長さをとり算出し た港内の第 1 固有振動周期が 510 秒程度になることか ら, 副振動成分によるものと推察される. 以上の結果, 500 秒程度で卓越する長周期波は風によって生じ, 副 振動により発達するものと考えられる. 同図 (b) は, 水圧データを正時毎に平均した值を用いて, 再度 FFT 解析を行った結果を示す. 12 時間周期で卓越する波の パワースペクトルは, 周期が 500 秒程度の長周期波に 比較して，3 オーダ程度大きくなっている．1昼夜観 測期間中の港奥海域の流動は，この 12 時間周期の波 に支配されているものと推察される.

\section{（3）マルチレベルモデルによる港内の流動解析}

前述の 1 昼夜観測期間中における港内の流動を準 3 次元多層モデルであるマルチレベルモデル ${ }^{3)}$ によって 計算する。 このモデルは, 静水面上に $x$ 軸及び $y$ 軸を 取り, 水深方向 $(z$ 軸) に分割された各層における連 続式及び運動方程式, 塩素量及び水温に関する移流拡 散方程式から構成され, 密度と塩素量及び水温の関係 式には, Knudsen の状態方程式 ${ }^{4)}$ が用いられる. 図 -4 は計算対象領域を示寸. 計算メッシュは平成 10 年度 の深浅測量結果に基づき，平面方向に $25 \mathrm{~m}$ 間隔で分割 し，鉛直方向には 1 昼夜観測と同様に，上層から順に 静水面下 $-2 \mathrm{~m},-4 \mathrm{~m},-6 \mathrm{~m}$ の 3 層で重層化させた。前出の FFT 解析の結果から，12 時間周期の波を発生させる外 力は他にも考えられるが, ここでは既往の流況調査報

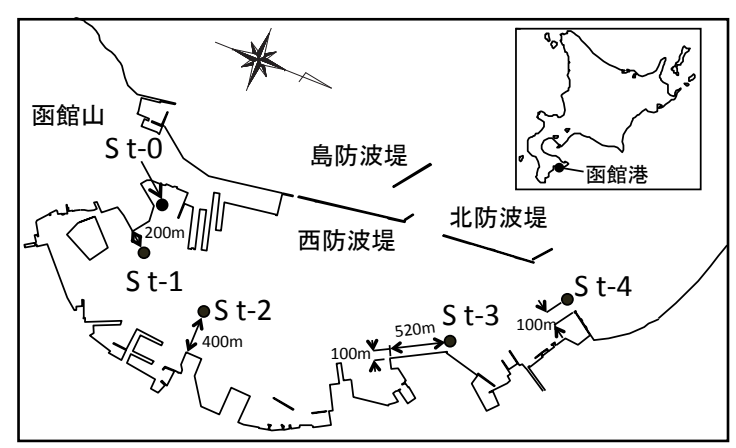

図 -1 現地観測の調査位置

表 -1 1 昼夜観測の計測項目

\begin{tabular}{|c|c|c|c|c|c|}
\hline & 期間 & 層(水深) & 間隔 & 時間 & サンプリング \\
\hline 水位 & \multirow{7}{*}{\begin{tabular}{|l}
25 25時間 \\
$(9 / 27272100$ \\
$\sim 9 / 28$ 12:00)
\end{tabular}} & T.P.-2.0m & \multirow{4}{*}{ 1時間 } & 20分 & 0.5 秒 \\
\hline DO & & \multirow{6}{*}{$\begin{array}{c}\text { 上層 } \\
\text { (T.P.P. } \\
\text { 中層 } \\
\text { (T.P. } \\
\text { 下. 層 } \\
\text { (T.P. } 6 \text { ) } \\
\text { (t.Om) }\end{array}$} & & \multirow{3}{*}{\multicolumn{2}{|c|}{$\begin{array}{l}\text { 計測器を所定水深に沈め } \\
\text { て測定. }\end{array}$}} \\
\hline 水温 & & & & & \\
\hline $\mathrm{CL}$ & & & & & \\
\hline 濁度 & & & \multirow{3}{*}{ 6時間 } & \multirow{3}{*}{\multicolumn{2}{|c|}{$\begin{array}{l}\text { 所定水深の海水を採水器 } \\
\text { にり取得した後, 吸光光 } \\
\text { 度計によつて測定. }\end{array}$}} \\
\hline COD & & & & & \\
\hline TP & & & & & \\
\hline
\end{tabular}

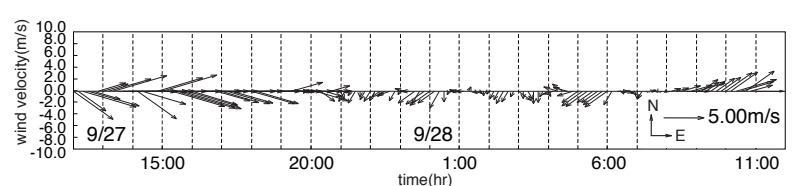

(a) 風速ベクトル分布

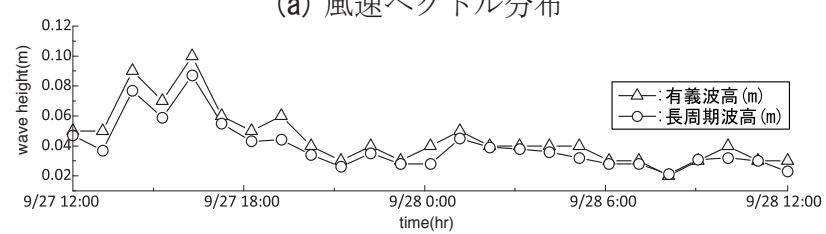

(b) 波高分布

図 -2 観測期間中の風と波浪の関係

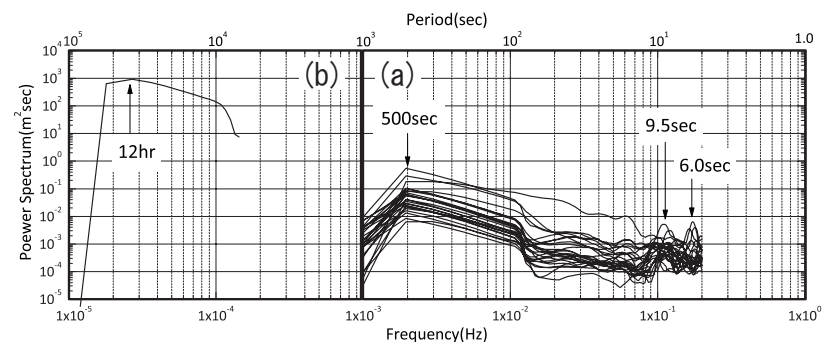

図 -3 観測期間中における水位のパワースペクトル

告書 ${ }^{5}$ から主要 4 分潮のうち 1 日 2 回潮の $\mathrm{S}_{2}$ 分潮及 び $\mathrm{M}_{2}$ 分潮の振幅流速を正弦波として, 図中の $\mathrm{AB}$ 及び BC の境界に与えた. 図 -5 (a) 及び (b) は, 前述の 1 昼 夜観測で得た港奥海域における水温及び塩素量の経時 変化を示す. 水温及び塩素量は微小な変動があるもの の, 全層にわたりほぼ均一な分布を保持しながら観測 期間中, 概水一定で推移する傾向にある. 既往の水質 調查報告書 ${ }^{6}$ から 1 昼夜観測とほぼ同期間に得た港外 の塩素量及び水温の経年值と比較した結果, 港内と港 外での差は小さいことから, 本解析では塩素量及び水 温を計算領域で一定と仮定し，1 昼夜観測の值を与え た。 また, 計算領域の北側に位置する七重浜海岸には 
函館湾に注ぐいくつかの流入河川が存在するが，平常 時の河川流量が小さく, 詳細な観測が行われていない. そのため, 本計算は流入河川を考慮せず計算を行った.

図 -6 は 1 昼夜観測と同位置の $S_{2}$ 及び $M_{2}$ 分潮の潮位 を個別に計算した結果と観測潮位の比較を示す． $\mathrm{M}_{2}$ 分 潮の計算潮位は, $\mathrm{S}_{2}$ 分潮に比較して潮位の変化が小さ く, 1 昼夜観測期間中における観測潮位は， $\mathrm{S}_{2}$ 分潮の 影響が大きいものと考えられる.

\section{（4）港奥海域における水質の日変動特性}

図-7 は港奥海域における各水質の経時変化を示 す. 同図 (b) に示寸濁度は上・中層よりも下層で高く, 9/27 の 18:00 及び 9/28 の 6:00 では他層に比して 2 オーダ程度高い值を示す。この濁度が高くなる時間帯 は前出の図 -5 において, 下げ潮最強時にほぼ一致し, 図 -7 (a) に示寸 1 昼夜観測と同位置で得た $\mathrm{S}_{2}$ 分潮にお ける下層流速の計算值が最大となる。 この結果, 下げ 潮最強時の潮流によって底質が巻き上げられたものと 推察される. 同図 (c) は COD の経時変化を示す. COD は濁度と同様に下層で常に高く推移しており，それに 追従するように上・中層の COD が増加している．観測 期間中, 下層の COD が特に高くなる時間帯は, 同図 （b）で示した下層の濁度が高くなる 9/27 の 18:00 及び 9/28 の 6:00 に一致する.これは, 下げ潮最強時の潮 流によって底質に含まれるへドロや底生生物等が同時 に巻き上げられたことに起因する。同図 (d) はD０の 経時変化を示し, 図中の実線は飽和溶存酸素量を示す. D0 は全層において 9/27 の 12:00 から 16:00 まで高い 值で推移しているが, その後, 減少する傾向にある. 特に下層では一時的に貧酸素水塊を形成している。こ れより，下げ潮最強時の底質の巻き上げにより海中に 含まれる被酸化性物質の濃度が高まった結果, 酸素の 内部消費が一層加速しているものと考えられる。一方, 同図 (e) に示寸 T-P は，上層において 9/27 の 12:00 から 18:00の間で高く推移する。これは中・下層の $\mathrm{T}$-P の值を考慮すると，下げ潮時の潮流によって輸送 された成分と考えられる。この上層の T-P は， 9/28の 18:00 から 3:00の潮流流速が減速寸る満潮時に向かっ て中層ならびに下層へ沈降することが認められる.

\section{3. 函館港における栄養塩の供給源に関する検討}

\section{（1）函館港全域を対象した水質観測}

港内に蓄積する栄養塩の供給源を検討するため, 前 出の図 -1 中の St $-1 \sim \mathrm{St}-4$ に示寸港湾全域を対象と した現地観測を実施した。期間は 2008 年 10 月〜 12 月の 3 ケ月間であり, 月 1 回の割合で各観測点におけ る $\mathrm{T}-\mathrm{N} ， \mathrm{~T}-\mathrm{P} ， \mathrm{COD} ， \mathrm{D} 0$ を前述の 1 昼夜観測と同様な 計測方法によって，それぞれT.P. から $-2 \mathrm{~m}$ (上層), $-4 \mathrm{~m}$ (中層),$-6 \mathrm{~m}$ (下層) 地点で測定した。

図 -8 及び 9,10 中の (a)，(b)，(c)，(d) は，10月

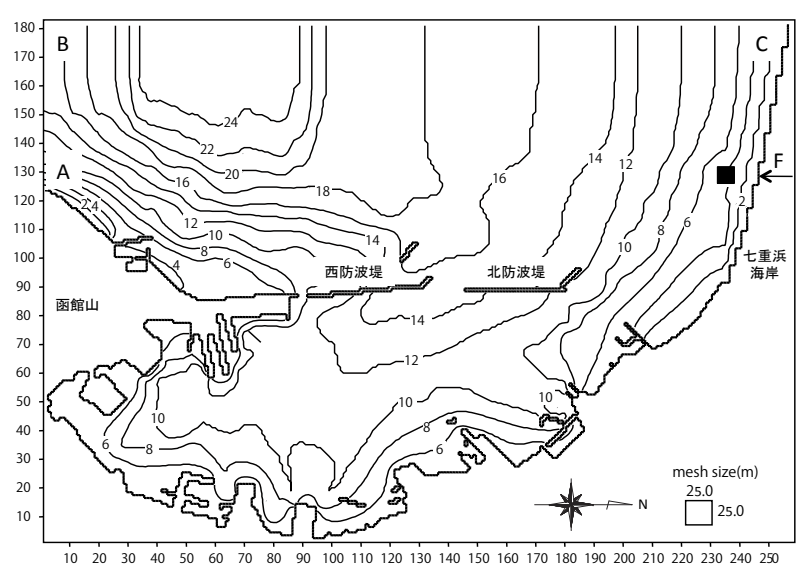

図 -4 計算対象領域

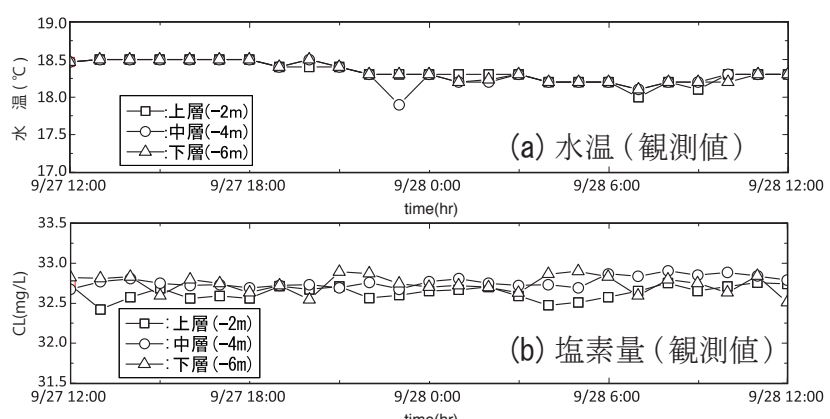

図 -5 水温及び塩素量の観測值

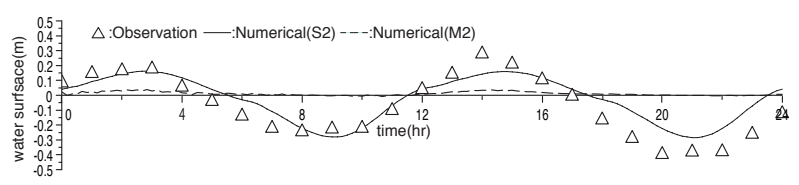

図 -6 計算潮位と実測潮位の比較
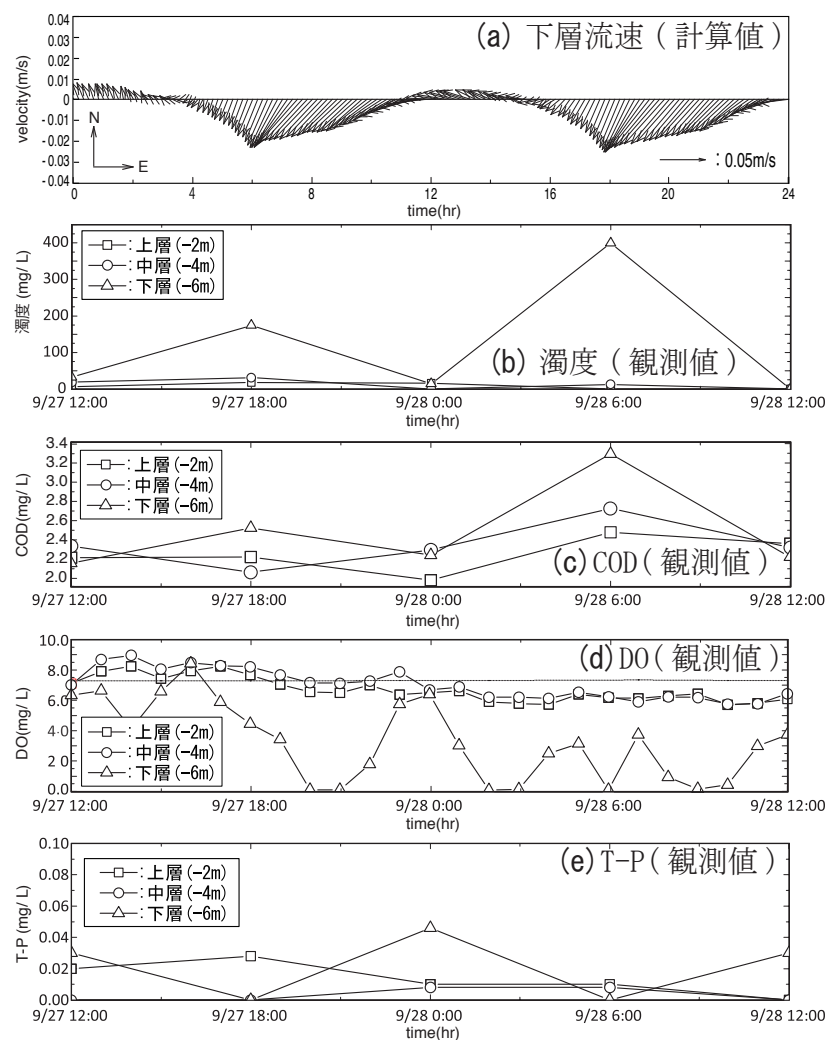

図 -7 観測期間中の各水質の日変動変化 
及び 11 月， 12 月の各観測点で層平均した T-N, T-P, COD，DOの港内分布を示す。また，同図（a）中には観 測日より 4 日前の降水量を表示する. 図 -8 及び 9 中 の（a）に示す観測日より 4 日前に降水量が少ない 10 月及び 11 月の $\mathrm{T}-\mathrm{N}$ は, 港口から港奥海域に向かって 高く推移する。これは同図 (b) に示す同期間の T-P に おいても同様であり，栄養塩は閉鎖性の強い港奥海 域に蓄積する傾向があると考えられる。これに対し， 観測日より 4 日前に降水がある 12 月の $\mathrm{T}-\mathrm{P}$ を示す図 -10 (b) では，降水量の少ない 10 月及び 11 月に比し て港湾全域で高い值となっている。この結果，港奥海 域に蓄積する $\mathrm{T}-\mathrm{P}$ は，降水に伴い港口から港奥へ輸送 されるものと推察される.これに対し, 図-10(a) に 示す 12 月の $\mathrm{T}-\mathrm{N}$ は逆に，港湾全域で低下することか ら，その輸送過程は $\mathrm{T}-\mathrm{P}$ とは異なる原因によるものと 考えられる. 図 -8 及び 9,10 中の (c) は 10 月及び 11 月, 12 月の COD 分布を示す. 10 月の COD は 11 月及び 12 月の場合に比較して, 港湾全域で高い值を示す。こ れに対し，11月及び 12 月のCOD はともに，同程度の 值で港湾全域にほぼ均一に分布し, 降水に伴う変化は 見られない. 図 -8 及び 9,10 中の (d) は 10 月及び 11 月, 12 月の D 0 分布を示す. 降水量の少ない 10 月及び 11 月の D 0 は T-P ならびに T-N と同様に港奥海域で高 い值になる。一方，4 日前に降水がある 12 月の D0 は, 港湾全域で高い值となり，同時期における $\mathrm{T}-\mathrm{P}$ の港内 分布の傾向に一致する. 以上の結果，港内の D 0 の消 長は，他にも要因が考えられるが， T-Nに比較すると，
降水に伴い港口から港奥に輸送される $\mathrm{T}-\mathrm{P}$ と高い相関 があると考えられる。

\section{(2) 粒子追跡解析}

前出の図-4において，七重浜海岸には函館湾に注 ぐ流入河川が幾つかある。その中でも図中の F に示す 流入河川は，上流域に農地及び富栄養化で問題となっ ている湖沼を有していることから，降水時には大量の 栄養塩の流入が想定される。しかし前述のように, こ の河川に関する流入流量や水質に関する詳細な観測 は行われていない. そこで, 本研究は図中のロで示す 河川の前面海域にトレーサ粒子を 400 個配置し，オイ ラー・ラクランジュ法 ${ }^{7)}$ による追跡解析を行った。粒 子を移動させる港湾周辺海域の流動は, 降水後の河川 増水に伴う淡水流入による影響が考えられるが，ここ では $\mathrm{S}_{2}$ 分潮の潮流流速のみを用いて計算を行った.

図-11 は，30日間移動させたトレーサ粒子分布及び $\mathrm{S}_{2}$ 分潮の潮汐残差流ベクトル分布を示す. 河川前面海 域に配置したトレーサ粒子は, 函館山側から流入し, 七重浜海岸で南東方向に流れを転じる潮汐残差流によ り, 第 3 航路港口から港内に輸送され, 流れの停滞す る港奥海域に蓄積していることが認められる。T-P は 本解析で用いたトレーサ粒子とは違い, 植物プランク トンによる生産・分解ならびに沈降作用等により非保 存物質である。しかし, 港奥側に輸送される過程は港 湾全域における現地観測の傾向とよく一致することか ら, 定性的ではあるが, 港内の T-P は函館湾に注ぐ流

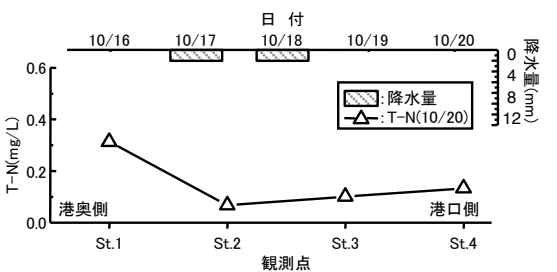

(a) $\mathrm{T}-\mathrm{N}$ 分布

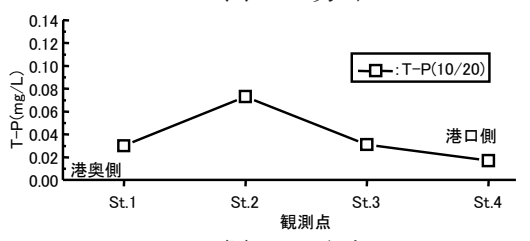

(b) $\mathrm{T}-\mathrm{P}$ 分布

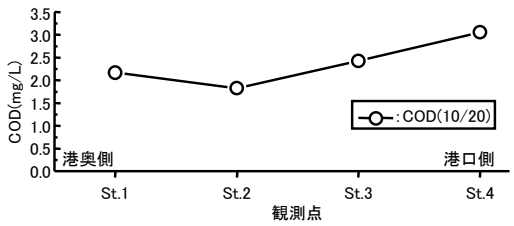

(c) COD 分布

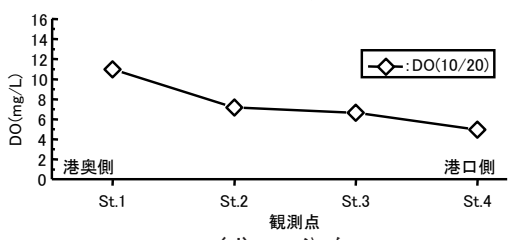

(d) DO 分布

図 -8 10 月の観測結果

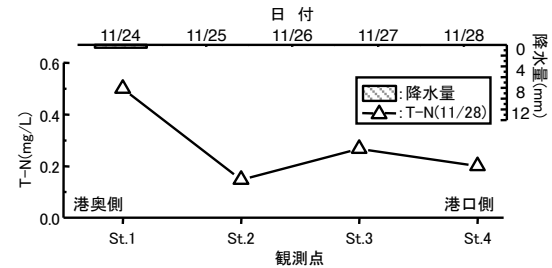

(a) $\mathrm{T}-\mathrm{N}$ 分布

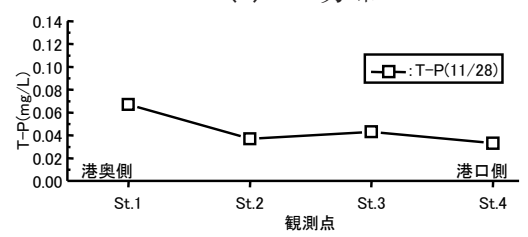

(b) T-P 分布

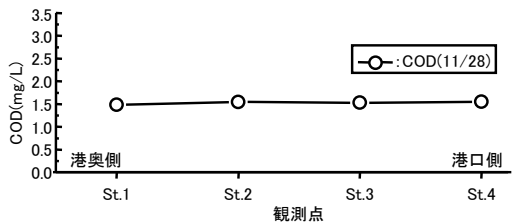

(c) COD 分布

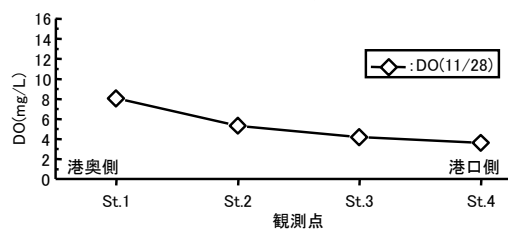

(d) DO 分布

図 -9 11 月の観測結果

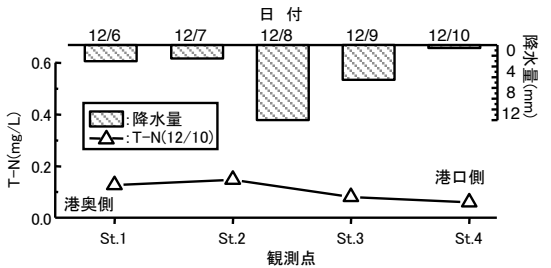

(a) $\mathrm{T}-\mathrm{N}$ 分布

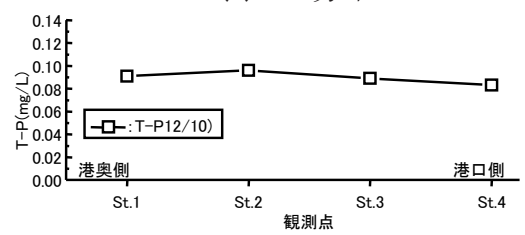

(b) T-P 分布

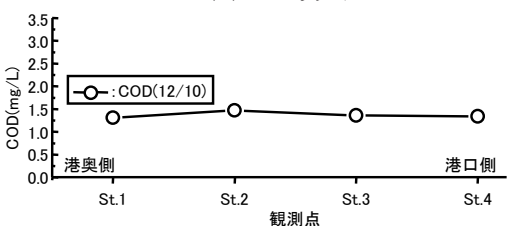

(c) COD 分布

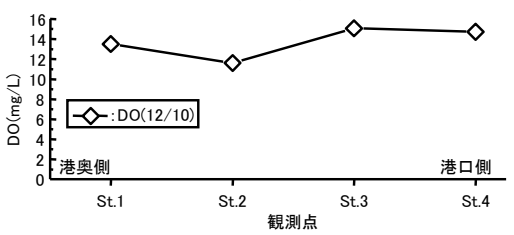

(d) DO 分布

図 -10 12 月の観測結果 
入河川から供給されるものと推察される.

\section{4. 港湾周辺海域の水質環境モデルの構築}

\section{(1) 生態系モデルの構築}

前述した 1 尽夜連続観測の水質を定量的に評価可能 な函館港における水質環境モデルを構築する．生態系 モデルは堀江ら ${ }^{8)}$ による物質循環に基づく生態系モデ ルを参考にして構築した．生態系モデルの概念図を図 -12 に示す. 生態系は栄養塩 - 植物プランクトンの段 階に留め, 海中の D 0 及び COD は, 港湾全域の現地観 測において, T-P が D0 の変化とよい相関を示したため, リンのみを栄養塩の制御因子として生産・分解するも のとした. 水深方向には前出の現地観測と同様に 3 層 設け，上・中層を有光層，下層は無光層とし，生産は 有光層のみで生じるものとすると, 有機態リン $(0 \mathrm{P})$, 無機態リン (IP)，COD，D0 に関する物質収支式は以下 のようになる.

$$
\begin{aligned}
& \frac{\partial}{\partial t}\left[O P_{k} \cdot h_{k}\right]=\left\{\begin{array}{ll}
G \cdot O P_{k} \cdot h_{k}(k=1,2) \\
0 & (k=3)
\end{array}\right\} \\
& -B_{k}^{P} \cdot O P_{k} \cdot h_{k}+\left\{\begin{array}{lr}
-S_{k}^{P} \cdot O P_{k} & (k=1) \\
-S_{k}^{P} \cdot O P_{k}+S_{k-1}^{P} \cdot O P_{k-1}(k=2,3)
\end{array}\right\} \\
& \frac{\partial}{\partial t}\left[I P_{k} \cdot h_{k}\right]=\left\{\begin{array}{ll}
-G \cdot O P_{k} \cdot h_{k}(k=1,2) \\
0 & (k=3)
\end{array}\right\} \\
& +B_{k}^{P} \cdot O P_{k} \cdot h_{k}+\left\{\begin{array}{ll}
0 & (k=1,2) \\
R_{I P}(k=3)
\end{array}\right\} \\
& \frac{\partial}{\partial t}\left[C^{2 O D_{k}} \cdot h_{k}\right]=\left\{\begin{array}{ll}
\beta \cdot G \cdot O P_{k} \cdot h_{k}(k=1,2) \\
0 & (k=3)
\end{array}\right\} \\
& -B_{k}^{C} \cdot C O D_{k} \cdot h_{k} \\
& +\left\{\begin{array}{lc}
-S_{k}^{C} \cdot C O D_{k} & (k=1) \\
-S_{k}^{C} \cdot C O D_{k}+S_{k-1}^{C} \cdot C O D_{k-1}+R_{C O D}(k=2,3)
\end{array}\right\} \\
& \frac{\partial}{\partial t}\left[D O_{k} \cdot h_{k}\right]=\left\{\begin{array}{ll}
\alpha \cdot G \cdot O P_{k} \cdot h_{k}(k=1,2) \\
0 & (k=3)
\end{array}\right\} \\
& -B_{k}^{D} \cdot C O D_{k} \cdot h_{k} \\
& +\left\{\begin{array}{lr}
m\left(H O W A-D O_{1}\right) \cdot h_{1}(k=1) \\
0 & (k=2) \\
-D_{B} & (k=3)
\end{array}\right\}
\end{aligned}
$$

ここに, $h_{k}$ は第 $k$ 層の層厚, 下添字 $k$ は 1 を上層とす る層番号， $O P_{k}, I P_{k}, C O D_{k}, D O_{k}$ はそれぞれ第 $k$ 層の 有機態リン, 無機態リン, 化学的酸素要求量, 溶存酸 素量を示す. $G$ は生産速度, $B^{P}{ }_{k}, B^{C}{ }_{k}$ はそれぞれ第 $k$ 層の $O P$ 及び $C O D$ の分解速度であり, $B^{D}{ }_{k}$ は分解に伴 う酸素消費速度を示寸. $S^{P}{ }_{k}, S^{C}{ }_{k}$ 注第 $k$ 層の $O P$ 及び $C O D$ の沈降速度, $m$ は曝気係数, HOWA は飽和酸素量, $\alpha, \beta$ はそれぞれ $D O$ 及び $C O D$ の換算係数， $R_{I P}$ はリン の溶出速度である。これらの生態系モデルに含まれる

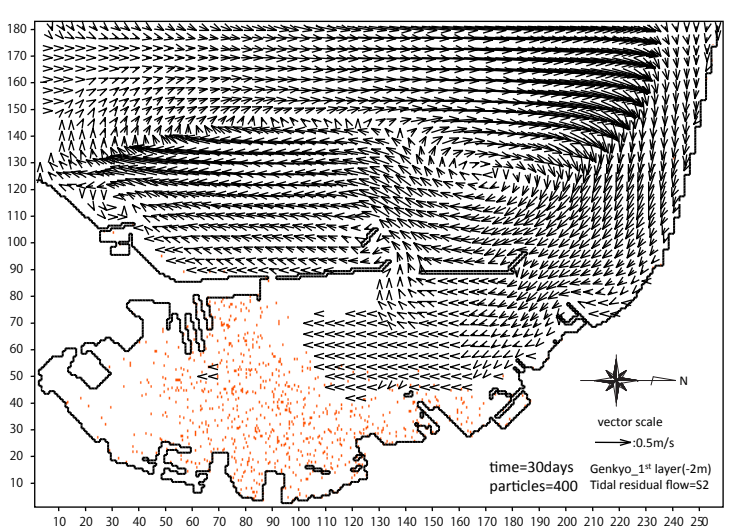

図 -11 トレーサ粒子分布及び潮汐残差流ベクトル分布

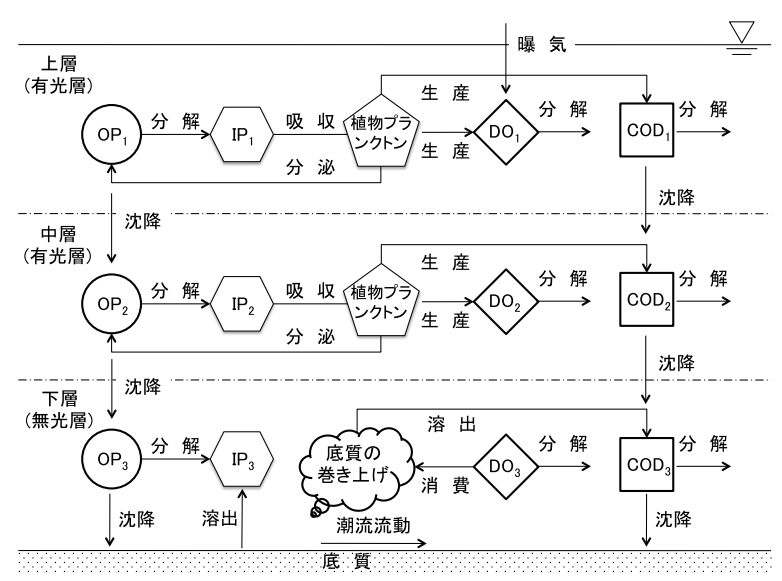

図-12 生態系モデルの概念図

定数は, 堀江ら ${ }^{8)}$ が提示した基準值を準用した。 また, $R_{C O D}$ 及び $D_{B}$ はそれぞれ，底質の巻き上げによる $C O D$ の溶出速度ならびに酸素消費速度であり, 以下の手順 で計算を行った. はじめに予め求めたマルチレベルモ デルによる下層の潮流合成流速 $q$ と濁度 $P_{s}$ の観測值の 関係から, 以下の曲線式を用いて,

$$
P_{s}=M\left(q / q_{c r}-1\right)^{n}
$$

濁度を計算した後, 次に $C O D$ の溶出速度及び酸素消 費速度は, 以下の直線式より算出した。

$$
R_{C O D}=-D_{B}=G_{P} \cdot P_{s}
$$

ここに, $M, n, G p$ は定数, $q_{c r}$ は巻き上げ限界流速であり, 現地観測及び解析結果に基づき定めた。 以上の（1）式 から（6）式は, 前出のマルチレベルモデルによる港内 の流動解析において, $O P, I P, C O D, D O$ に関寸る移 流拡散方程式を新たに追加し, その生物反応項として 組み込夕計算を行った。流動解析に関する計算条件は 前出と同様とし，港内・外に与える各水質に関する初 期值及び境界条件は，観測結果に基づき決定した。

\section{（2） 1 昼夜連続観測の再現計算}

図-13(a)，(b)，(c) はそれぞれ COD，D0，T-P の計 算值と 1 昼夜観測で得た観測值の比較を示し, T-Pの 計算值は有機態リン OP と無機態リン IP の総和とし て表示する. 同図（a）に示寸 COD の計算值は，下層に 
おいて下げ潮最強時の底質の巻き上げ作用により増加 し，その生起時間はやや遅延するものの，1昼夜観測 と同様な傾向が得られる。これに対し，同図 (b) に示 す下層におけるD０の計算值は，現地と同様に下げ潮 最強時の COD の増加に伴い低下するが，現地で生じた 貧酸素水塊を十分に再現できていない。また, 同図 (c) に示す T-P は，下層において沈降・溶出を十分に再現 できず，現地観測の傾向とは異なる結果となる．以上 のように下層の再現精度にはやや課題が残るものの, 上・中層における COD, D 0, T-P の計算值は，観測值 とぼぼ同様な傾向で推移しており，定性的ではあるが， 概ね良好な結果を予測することができる。

\section{6. 結 論}

本研究で得られた結論を要約すると，下記のとおり である。

（1） 1 昼夜観測において，港奥海域の下層における D 0 の低下は，下げ潮時に生じる底質の巻き上げによって， 海中の被酸化性物質の濃度が高まり, 酸素の内部消費 が一層加速したことに起因するものと考えられる.

（2）港湾全域を対象とした水質観測の結果，港内にお ける D0 の変化は，他にも要因が考えられるが，T-Nに 比較すると，降水に伴い港口から港奥に輸送される T-P と高い相関があると考えられる。

（3）塩素量や水温の変化及び流入河川の影響を無視し た条件で取り扱ったマルチレベルモデルに，物質循環 に基づく生態系モデルを組み込んだ水質環境モデル は，港内の流動や下層での水質の再現精度に課題が 残っており，今後計算精度を高める必要がある。

今後は，函館湾に注ぐ流入河川の流量及び港湾全域 を対象とした水温及び塩素量を含めた水質の長期観測 を実施し，より詳細な現象を把握するとともに，マル チレベルモデルならびに，水質環境モデルの予測計算 精度を向上させる所存である。

謝辞：本研究を遂行するにあたっては，総務省「戦略 的情報通信研究開発推進制度 (SCOPE)」の研究助成金 による補助を受けたことをここに記し，謝意を表す。

\section{参考文献}

1）函館市：国産水産・海洋総合研究センターの整備に向け た提案書 II , pp. 10-17, 2006.

2）宮武誠, 湊 賢一, 本村真治, 松村一弘, 増田 亨, 吉江祐人：自律駆動型水素吸蔵合金アクチュエータを利用し た函館港の海水交換装置の検討，海洋開発論文集，第 26 巻， pp. 81-86, 2010.

3) J.J.Leendertse,R.C.Alexander and S.K.Liu:A three dimensional model for estuary and coastal seas vol.1 priciple of

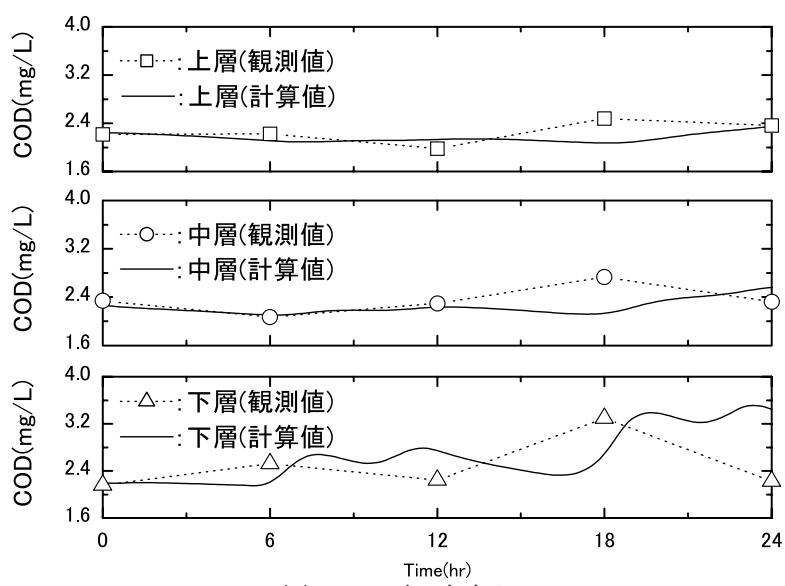

(a) COD の経時変化

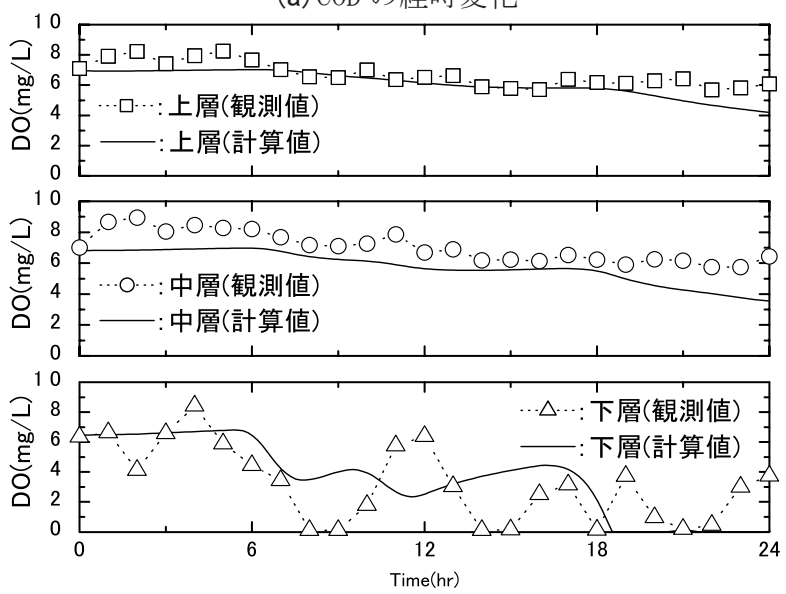

(b) D0 の経時変化

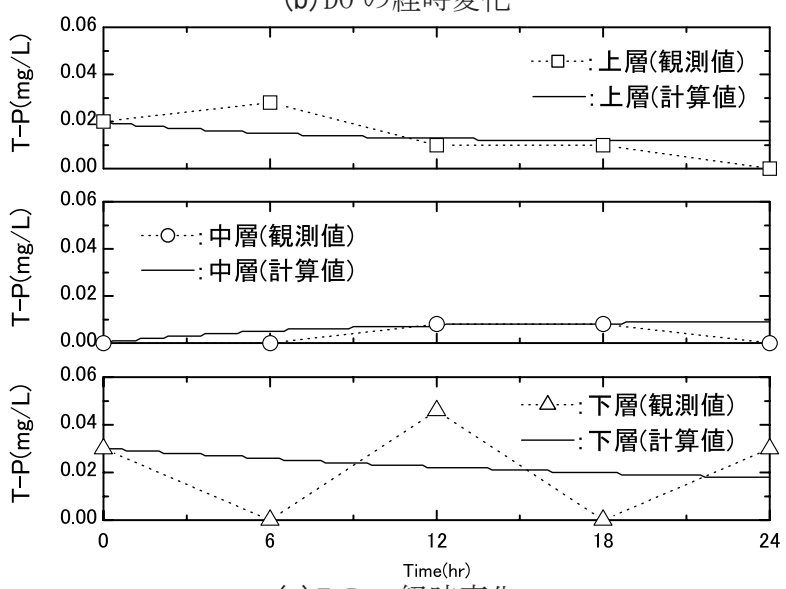

(c) T-P の経時変化

図 -13 水質環境モデルによる計算值と観測值の比較

computation, The Rand Corporation,R-1417-OWPR,1973.

4）松梨順三郎, 池田有光, 海老瀬潜一, 吉田喜三郎 : 環境 流体污染，森北出版株式会社，pp. 170-171, 1996.

5）北海道開発局 函館開発建設部：平成 9 年度 函館港流況 調查報告書，pp. 50-59, 1997 .

6）北海道開発局 函館開発建設部：平成 10 年度 函館港水 質調查業務報告書, pp. 57-99, 1998 .

7）今里哲久:海水交換の概念と交換率, 沿岸海洋研究ノート, 30 周年記念特別号, pp. 111-123, 1993.

8）堀江 毅, 細川恭史 : 海域における物質循環数值モデル の水質支配要因について, 港湾技術研究所報告, 運輸省港湾 技術研究所, Vol. 22, No. 3, 1998. 